\title{
Chapter 7 \\ Transnationalism as a Research Paradigm and Its Relevance for Integration
}

\author{
Liza Mügge
}

\section{Introduction ${ }^{1}$}

Interest in the transnational involvement of immigrants has grown rapidly since 1994, when Bash, Glick Schiller, and Szanton Blanc published their pioneering book Nations Unbound. This book is considered the first major study of migrant transnationalism. In it, the authors stress the various forms of contact that a substantial group of migrants maintain with their country of origin. The study of transnationalism is strongly rooted in anthropology. Its early authors, like Basch et al. 1994, were US-based anthropologists with fieldwork experience in migrants' host country and country of origin (Foner 2000, 49). In Europe, transnational research gained firm ground in 1997 when the Institute of Social and Cultural Anthropology of the University of Oxford hosted a five-year research programme on transnational communities (Transcomm, see www.transcomm.ox.ac.uk). Linked projects were conducted in single disciplines or were multidisciplinary. Transcomm marked the emergence of a flourishing research field spanning a range of disciplines in the social sciences and humanities, including sociology, anthropology, political science, law, history, media studies, and geography. Top European journals, like Global Networks, Ethnic and Racial Studies, and the Journal of Ethnic and Migration Studies, have featured numerous studies and special issues on migrant transnationalism. Despite the field's interdisciplinary approach and scope, disciplinary flavours remain traceable in the topics selected, research designs, and the methodologies applied.

\footnotetext{
${ }^{1}$ I thank Blanca Garcés- Mascareñas and Rinus Penninx for their comments on earlier versions of this chapter.
}

L. Mügge $(\square)$

University of Amsterdam, Amsterdam, The Netherlands

e-mail: L.M.Mugge@uva.nl 
Fuelled by securitization and politicization of migration, transnationalism also began to attract considerable attention in public debate around the turn of the millennium. Politicians, journalists, and policymakers questioned whether transnationalism might undermine immigrants' integration. During the past decade, European leaders across the political spectrum have expressed concern about migrants' loyalties and involvements that could potentially compromise their territorial borders (Mügge 2012a). Loyalty towards the country of origin (or that of parents) became the litmus test of integration. According to Østergaard-Nielsen (2011), citizens who live their lives across borders pose distinct challenges to policymakers. The idea of "integration here" and "development there" forces governments to rethink their integration models.

This chapter reviews the state of the art of scholarship on the transnationalismintegration nexus. It examines the view emanating from the existing literature on the relation between immigrants' transnational activities and ties to the country of origin, on the one hand, and "integration" in the receiving country, on the other. The review is guided by the popular political question: Can transnationalism and integration be mutually beneficial, or is it a zero-sum relation? The next section outlines the emergence of transnationalism as a research paradigm and its relation to academic research on integration. The chapter then dedicates a section to each of the main dimension of transnationalism in Europe: economic, political, and sociocultural. Finally, routes are suggested for future policy-oriented research.

\section{New Ways of Thinking About Integration: The Transnationalism Paradigm ${ }^{2}$}

Over the past 20 years, transnationalism emerged as one of the major research paradigms in migration and ethnic studies (Dunn 2005; Mügge and De Jong 2013). Transnationalism is a container concept and is applied to reveal and understand the ties and activities developed between individual, collective, or governmental actors located in two or more countries. 'A transnationalism paradigm encourages holistic analysis of movement (including immigration but also subsequent visitation and communication), and it transcends some of the assimilationist assumptions of earlier migration policy and research' (Dunn 2010, 3).

To study transnationalism empirically, scholars have attempted to classify transnational activities by differentiating between economic, political, and sociocultural aspects and whether these take place in the home country or host country (Portes et al. 1999, 222; Al-Ali et al. 2001, 618-626; Portes 2001, 187). Table 7.1 presents various examples of such classification. Economic activities include remittances to and investments in the homeland as well as donations to migrant organizations. Transnational sociocultural activities encompass, for instance, visits to friends and

\footnotetext{
${ }^{2}$ The first part of this section draws on Mügge (2010, 36-39), though the text has been reorganized and reinterpreted for the purpose of this contribution.
} 
Table 7.1 Classification of transnational activities and their degree of institutionalization

\begin{tabular}{l|l|l|l}
\hline & Economic & Political & Sociocultural \\
\hline High institutionalization & $\begin{array}{l}\text { Informal trade } \\
\text { between home } \\
\text { and host country }\end{array}$ & $\begin{array}{l}\text { Home town } \\
\text { community groups } \\
\text { created by migrants }\end{array}$ & $\begin{array}{l}\text { Amateur sports } \\
\text { matches between } \\
\text { home and host } \\
\text { country }\end{array}$ \\
\cline { 2 - 4 } & $\begin{array}{l}\text { Small businesses } \\
\text { created by returned } \\
\text { migrants }\end{array}$ & $\begin{array}{l}\text { Alliances of } \\
\text { immigrant } \\
\text { committees with } \\
\text { home country } \\
\text { political associations }\end{array}$ & $\begin{array}{l}\text { Homeland folk music } \\
\text { groups giving } \\
\text { presentations in } \\
\text { immigrant centres }\end{array}$ \\
\hline & $\begin{array}{l}\text { Circular } \\
\text { international } \\
\text { labour migration } \\
\text { coundraisers for home } \\
\text { candidates }\end{array}$ & $\begin{array}{l}\text { Priests from the } \\
\text { hometown visit and } \\
\text { organize parishioners } \\
\text { abroad }\end{array}$ \\
\cline { 2 - 4 } & $\begin{array}{l}\text { Investments by } \\
\text { multinationals in } \\
\text { the homeland } \\
\text { mediated by } \\
\text { migrants }\end{array}$ & $\begin{array}{l}\text { Consular officials } \\
\text { and representatives of } \\
\text { national political } \\
\text { parties abroad }\end{array}$ & $\begin{array}{l}\text { Imams sent by } \\
\text { homeland institutions } \\
\text { to visit and preach in } \\
\text { migrant mosques }\end{array}$ \\
\hline $\begin{array}{l}\text { Tourist locations } \\
\text { developed in the } \\
\text { homeland by } \\
\text { migrants }\end{array}$ & $\begin{array}{l}\text { Dual nationality } \\
\text { granted by home } \\
\text { country governments }\end{array}$ & $\begin{array}{l}\text { Major artists from } \\
\text { the home country } \\
\text { perform in countries } \\
\text { where compatriots } \\
\text { live }\end{array}$ \\
\hline & $\begin{array}{l}\text { Home country } \\
\text { banks in immigrant } \\
\text { centres }\end{array}$ & $\begin{array}{l}\text { Migrants elected to } \\
\text { home country } \\
\text { legislatures }\end{array}$ & $\begin{array}{l}\text { Regular cultural } \\
\text { events organized by } \\
\text { home country } \\
\text { embassies }\end{array}$ \\
\hline
\end{tabular}

Source: Adapted from Portes et al. (1999) and Mügge (2010, 37)

family. Participation in homeland elections is a form of transnational political activity. The distinction between economic, sociocultural, and political activities is an analytical one; in reality they overlap (see Van Amersfoort 2001).

To examine the durability of transnational activities, scholars assess their degree of institutionalization. Activities are institutionalized when they become predictable, constant, and structured (see Beerling 1978, cited in Penninx 1988). Activities are highly institutionalized when they are held on an organized and regular basis, such as annual festivals and congresses or weekly discussion groups governed by written or unwritten rules and attendance norms. Activities can also be distinguished by whether they are initiated and institutionalized from "above" or "below". Political initiatives institutionalized from above include governments' allowing migrants to be elected to home country legislatures. Initiatives from below include fundraising among migrants for hometown committees. The durability or persistence of transnational activities is important, since many scholars argue that the majority of migrants who are not_-or are only weakly_attached to the homeland "are clearly here to stay" (Kasinitz et al. 2002, 117). 
Scholars have further categorized transnational activities by distinguishing between various types of transnationalism (Koopmans et al. 2005; Mügge 2010). In particular, transnational activities may be said to take five forms (Table 7.2). The first is transplanted homeland activities, where habits or conflicts between ethnic groups in the homeland are transplanted to the immigrant community (see Koopmans et al. 2005, 126-127). The second type is transplanted immigrant activities, which emerge when migrants return to the homeland with skills and ideas acquired in the host country (Nell 2007). The third type is homeland-directed transnational activities. Here, migrants in the country of settlement direct their activities towards their country of origin. Homeland-directed politics generally consist of attempts to improve the legal, economic, and political status of particular groups in the homeland. Activities take place either in the host country or in the country of origin. The fourth type, diaspora activities, is a subset of homeland-directed transnational activities for groups that do not have a homeland. The fifth category is country of residence-directed transnational activities. Here, homeland-based groups mobilize to intervene on behalf of the group's interests in the country of settlement (see Koopmans et al. 2005, 127). This typology transforms the straightforward question "is transnationalism harmful for integration?" into "what types of transnational activities are harmful for integration?" It also underlines-to paraphrase Bivand Erdal and Oeppen $(2013,878)$ - the fact that transnationalism happens not only "there" but also "here" (e.g., via country of residence-directed transnationalism or transplanted homeland activities). Likewise, integration may happen both "here" and "there", through transplanted immigrant or homeland-directed activities.

Scholars take different positions in describing the relation between transnationalism and integration. Bivand Erdal and Oeppen (2013, 872-875) distinguish four positions in the current literature: alarmist, less alarmist but pessimistic, positive, and pragmatic. First, the alarmist perspective views transnationalism as challenging or even preventing migrant integration (ibid., 872). Such fear is particularly great with respect to violent forms of transplanted homeland transnationalism, when homeland conflicts are imported to receiving societies and expected to threaten national security. Koopmans et al. $(2005,142)$ argue that strong transnational orien-

Table 7.2 Typology of transnational activities

\begin{tabular}{l|l}
\hline General type & Example \\
\hline Transplanted homeland activities & $\begin{array}{l}\text { Homeland political conflicts are transplanted to the host } \\
\text { country }\end{array}$ \\
\hline Transplanted immigrant activities & $\begin{array}{l}\text { Organizations set up in the host country are transplanted to } \\
\text { the country of origin }\end{array}$ \\
\hline Homeland-directed activities & $\begin{array}{l}\text { Host country-based groups support or oppose groups or } \\
\text { institutions in the homeland }\end{array}$ \\
\hline Diaspora activities & $\begin{array}{l}\text { Homeland-directed politics among groups without a } \\
\text { homeland or who consider their homeland occupied }\end{array}$ \\
\hline $\begin{array}{l}\text { Country of residence-directed } \\
\text { transnational activities }\end{array}$ & $\begin{array}{l}\text { Homeland-based actors set up institutions for their (former) } \\
\text { compatriots in the host country }\end{array}$ \\
\hline
\end{tabular}

Source: Adapted from Koopmans et al. (2005, 126-127) and Mügge (2010, 37) 
tations may be responses to exclusionary citizenship regimes in host states that limit migrants' access to the political community. Comparative studies of migrants in several European countries have found that at a collective level, migrant homelanddirected activism often takes violent forms. Strong homeland orientations are therefore argued to be detrimental to integration (Koopmans et al. 2005, 142). At a more symbolic level, authors suggest that exclusion by the dominant groups due to transnationalism being perceived as a sign of disloyalty is likely to reinforce migrants' diasporic or transnational ties with their own ethnic group (Wessendorf 2007 cited in Bivand Edal and Oeppen 2013, 872; Nagel 2009). Transnationalism triggered by exclusion from the receiving society is not expected to foster migrants' integration, as they are kept out regardless of their legal status.

Second, the less alarmist but also pessimistic position views migrants as engaging in transnationalism because it is their only option to survive in a new country where their 'cultural and human capital are not immediately applicable' (Bivand Erdal and Oeppen 2013, 872). This perspective foresees transnationalism as weakening over time, as its value diminishes as a survival mechanism.

The third view is termed the positive position. This is 'the idea that processes of integration and transnationalism [can] be mutually supportive' (ibid.). However, empirical findings differ on this issue. Studies in the USA have found migrants involved in transnational activities to be better-educated, longer-term residents of the host society, often active in local politics (Guarnizo et al. 2003, 1239; Portes et al. 2007, 276). In a study of integration and transnationalism among Canadian business migrants, Marger $(2006,898)$ concludes that adaptation of groups with sufficient human, financial, and cultural capital is more individualistic and approaches assimilation. In contrast, traditional labour migrants lacking such capital follow a more collectivist trajectory, using transnational ethnic networks in the adaption process. Snel, Engbersen, and Leerkes (2006) conclude in their comparative study of individual transnational involvement in the Netherlands that the more highly educated and employed respondents engaged in just as many transnational activities as those who were poorly educated, unemployed, and dependent on welfare (ibid., 304).

The final perspective is the pragmatic approach, which holds that 'the likely reality for the majority of migrants is more nuanced than an either/or choice between transnationalism and assimilation' (Bivand Erdal and Oeppen 2013, 873). The pragmatic approach is dominant in academic work. It states that transnationalism and integration (or in North American scholarship "assimilation") are not mutually exclusive. Influential in this respect are Levitt and Glick Schiller (2004, 1003), who argue that 'assimilation and enduring transnational ties are neither incompatible nor binary opposites'. Connections with the homeland and the receiving society occur simultaneously. Migrants may thus be integrated and transnational at the same time.

Presenting a less static view on transnationalism and integration, without geographically-bound outcomes (transnationalism=there; integration=here), Bivand Erdal and Oeppen $(2013,878)$ propose three alternative ways to capture the interaction between transnationalism and integration at the individual level: 'as additive (the result of the interaction is the sum of the two parts), as synergistic (the 
result is greater than the sum of the two parts) and as antagonistic (the result is less than the sum of the two parts, or one part even cancels out the other)'. For instance, feelings of belonging in both countries is additive. Synergistic interaction then occurs when feelings of belonging in one place render confidence to develop connections - and thus to invest in new feelings of belonging - in the other. Antagonistic interaction occurs when feelings of belonging in one place diminish feelings of belonging in the other (ibid.).

A focus on the interaction of integration and transnationalism offers a finergrained perspective than the alarmist, less alarmist but pessimistic, positive and pragmatic view. It shifts the question "are integration and transnationalism a zerosum game" to "how do integration and transnationalism influence one another". For instance, integration in one domain (e.g., economic) may change the type and form of transnationalism in that domain. However, Bivand Erdal \& Oeppen (ibid.) limit their typology to the individual level. This is constraining because-as the examples in Table 7.1 suggest - both integration and transnationalism involve collective and state actors (on integration see Penninx and Garcés-Mascareñas in this volume; on transnationalism see Mügge 2010). Moreover, organizations and states are often eager and highly motivated to invest in either transnationalism or integration in order to gain support for their own projects. Likewise, states and organizations may try to intervene in migrants' private lives if their integration or transnational route is going in the opposite direction of theirs. As Tables 7.1 and 7.2 indicate, one should differentiate between the forms and types of transnationalism as well as clearly specify how integration is defined in relation to a specific form and type of transnationalism. Integration, like transnationalism, is a multidimensional term (Ley 2013). The next sections review European scholarship from this perspective, drawing on the three main dimensions of transnationalism.

\section{Empirical Findings: Transnationalism and Integration in Europe}

Transnational scholarship developed in the USA earlier than in Europe. Much theory in this field is therefore based on the experiences of US immigrant groups that navigated in a context that is very different from the European (cf. Martiniello and Lafleur 2008). European research on transnationalism has matured during the past decade; this section takes stock of the recent empirical studies of economic, political, and sociocultural transnationalism. The field incorporates studies with a range of research questions and aims, a diversity of countries of origin and destination, and a variety of methodologies, from ethnography to surveys. Studies focus on a single ethnic group or are comparative in nature, focusing on one or more aspects of transnationalism. Authors agree that it is problematic to propose a causal relation between transnationalism and integration. For instance, following Kivisto (2001) and Vertovec (2009), Bivand Erdal and Oeppen $(2013,873)$ argue that a positive 
relationship between the two could be the result of the confidence migrants gain from social interaction, either transnational or not, which then becomes self-perpetuating.

Instead of looking for causality, this chapter presents an organized inventory of findings directed by the question of how integration and transnationalism might influence one another. Where studies have differentiated types and forms of transnationalism, this is taken into account. Despite tremendous variation in the studies reviewed in this chapter, most if not all point out the need to be attentive to diversity in transnationalism and integration: who-in terms of characteristics such as socioeconomic status, educational level, gender, ethnicity, religion, and migration motives-is involved in transnationalism, and who is not (cf. Mügge 2011)?

\section{Economic Transnational Activities}

Remittances are the form of transnationalism that is perhaps best monitored by supranational institutions as well as by sending and receiving countries. The World Bank estimates that global remittance flows, including those to high-income countries, reached US $\$ 542$ billion in 2013. That number is expected to have increased to $\$ 581$ billion in 2014 , of which $\$ 436$ billion flowed to developing countries. ${ }^{3}$ Europe's top five remittance-sending countries are Switzerland (\$19.6 billion), Germany ( $\$ 15.9$ billion), Italy ( $\$ 13$ billion), Spain ( $\$ 12.6$ billion), and Luxembourg ( $\$ 10.6$ billion). ${ }^{4}$ In view of the large amounts involved, sending states have shown great interest in trying to regulate remittances through formal channels. Classic labour-exporting countries, such as Turkey, have long been keen to manage these flows (Mügge 2013a). But "newer" sending countries too, such as Romania, have attempted to exercise significant state control over the money, people, and goods that cross its borders. In Romania this control diminished with the weakened macroeconomic situation in the 1990s, opening more opportunities for private and informal actors (Ban 2012). This is not a standalone pattern. Levitt and De la Dehesa (2003) found that Brazil and Mexico extend more state services to emigrants than Haiti and the Dominican Republic, in part due to the greater capacity of the former. Although countries like Haiti are heavily reliant on remittances, policy efforts to regulate these flows have been hindered by financial limitations and political instability. Portes, Escobar, and Radford (2007) present a similar conclusion for Colombia and the Dominican Republic.

Governmental regulation of remittances requires a well-functioning bureaucratic apparatus. Remittances from Europe to weak states are therefore largely informal. For instance, an estimated half of the population of Surinam receives material

\footnotetext{
${ }^{3}$ http://web.worldbank.org/WBSITE/EXTERNAL/NEWS/0,,contentMDK:20648762 pagePK:64 257043 piPK:437376 theSitePK:4607,00.html, accessed, 1 July 2014.

${ }^{4}$ http://siteresources.worldbank.org/INTPROSPECTS/Resources/334934-1199807908806/ Top10.pdf, accessed 1 July 2014.
} 
remittances, sent by $63.9 \%$ of the Surinamese residing in the Netherlands (Unger and Siegel 2006, 120). Unregistered remittances might equal the amount of remittances officially registered (ibid., 118). These inflows are one of the most stable sources of income for poverty relief at the household level in Surinam (Kruijt and Maks 2003). Informal remittance transfer channels are used by illegal migrants who may feel uncomfortable with established money transfer services or not know how to use them (Ban 2012, 137). Remittances may also be reverse. A study of Romanian immigrants in Italy found that migrants who were unemployed or had medical or legal problems received financial aid from their families back home (ibid.).

How do economic transnational activities relate to economic integration? Several European studies argue that there is a positive relation between upward social mobility in the country of destination and transnational commitments (e.g., Snel et al. 2006) or at least that these are not mutually exclusive (Mazzucato 2008). Drawing on findings from a comparative case study of remittance practices among two North African groups in France and one North Indian group in the UK, Lacroix $(2013,1023)$ argues that economic transnational activities hinge on (i) material and social resources resulting from social integration and (ii) patterns of identity formation. According to Lacroix (ibid.), Punjabis in the UK, benefitting from their relatively good economic integration, have been able to build public infrastructure such as hospitals and schools in their region of origin in India. Though the economic integration of Moroccan Berbers has been less favourable, these immigrants' integration into French civil society enabled them to link informal collectives of hometown citizens with external funding bodies (ibid., 1033). Kabyles have been incapable of establishing similar connections, due to a fragmented civil society resulting from the civil war in Algeria (ibid.). Carling and Hoelscher (2013) argue that migrants need both the capacity and the desire to send remittances. Capacity emerges from economic integration (e.g., secure employment and sound household finances), while desire may be fostered by identify formation. A quantitative survey of more than 3,000 immigrants in Norway (ibid.) and an ethnographic study of Somalis in the UK (Hammond 2013) both confirm that economic integration is decisive for remittance sending.

\section{Political Transnational Activities}

Transnationalism raises questions regarding the territoriality of citizenship and political participation (Collyer 2014). ${ }^{5}$ From a transnational perspective, political opportunities for participation are potentially shaped by both the receiving country and the sending country. Opportunities in the host country include aspects of legal status such as national asylum regimes, citizenship, voting, and access to legal representation, but also the migrant organizational landscape (Vertovec 2003, 654).

\footnotetext{
${ }^{5}$ This subsection draws on Mügge (2010, 28-30), though the text has been reorganized for the purpose of this contribution.
} 
The political opportunity structure in the country of origin refers to rights that enable the political participation of settled migrants, emigrants, and circular and return migrants, such as dual citizenship, external voting rights, and encouraging or discouraging the creation of political organizations (Mügge 2010, 30). Scholars have argued that strong transnational orientations are responses to exclusionary citizenship regimes in host states that limit migrants' access to the political community (Koopmans et al. 2005, 143). But sending states through the extension or denial of citizenship rights can include or exclude their (former) citizens from political participation as well (Freeman and Ögelman 1998). Depending on the citizenship regimes of both sending and receiving states, migrants may come to hold "dual" citizenship (Faist and Kivisto 2007).

Some studies of the political dimension of transnationalism find that transnational political participation goes hand in hand with political participation-and thus political integration - in the host country. Morawska (2003, 161-165), for example, argues that incorporation in local politics in the receiving society and political involvement in the country of origin are often successfully combined. There are numerous examples of diaspora groups that in response to homeland political developments have attempted to influence foreign policy in the country of settlement or a supranational level (see among others Weil 1974; Garett 1978; Arthur 1991; Jusdanis 1991; Shain 1999; Berkowitz and Mügge 2014). Not all agree that this is a good thing. Huntington (1997), for instance, argues that US foreign policy has become unduly dominated by migrants' interests. More positively, Mathias (1981) argues that such interests would otherwise be overlooked. Either way, migrant groups' ability to work the political system to the point of being able to influence foreign policy is itself a type of political integration. Certain types of transnational political activity thus seem to facilitate political integration.

European scholarship on transnational political activities and ties is particularly well developed on migrants from Turkey, most notably on the Kurds in Germany, the Netherlands, Sweden, and the UK (Wahlbeck 1999; Østergaard-Nielsen 2001; Van den Bos and Nell 2006; Eliassi 2013; Baser 2014; Alinea et al. 2014). The Kurds are spread over several European immigration countries. Due in part to the large number of political refugees among them, many Kurds have remained politically active around the situation in their homeland (Gunter 2008; Baser 2011). In the 1990s, when the Kurdish conflict in Turkey peaked and the Kurdish leader Abdullah Öcalan was arrested, Kurds across Europe protested against the Turkish state. Mass mobilization of Kurds and their "transplanted homeland politics" became a concern of European states. Koopmans et al. (2005) argue that such violent forms of transnationalism are detrimental to migrants' integration. However, the scope of such activities should not be overestimated. They are an exception rather than the rule (Mügge 2012b; on Sweden see, e.g., Khayati and Dahlstedt 2014). Beyond protesting at Turkish companies, embassies, and consulates, Kurdish organizations tried to influence Dutch foreign policy towards Turkey. To this end, many activities were organized, including hunger strikes, which imply profound knowledge of Dutch protest instruments. As such, these activists can be viewed as politically integrated into the Dutch system. Moreover, Kurds are extremely well 
organized at the European level. Dense networks have been established between organizations across Europe to facilitate joint homeland-directed politics. These networks are increasingly used as a platform for discussing common issues facing Kurds in Europe.

\section{Sociocultural Transnational Activities}

Research on sociocultural transnationalism and integration can be divided roughly into studies that quantitatively measure contacts with the country of origin and studies that focus on feelings of belonging. Engbersen et al. (2013) focus on attachment to the country of origin and attachment to, or integration in, the destination country of a relatively new group: post-accession migrants from Central and Eastern Europe. Based on a survey $(\mathrm{N}=654)$ among labour migrants in the Netherlands from Poland, Bulgaria, and Romania, these authors conclude that the strength of transnational ties and integration are influenced by patterns of labour migration. They propose four types (ibid., 976-978):

- Circular migrants strongly attached to the country of origin and weakly attached to the country of destination. Most migrants in this category were Polish and Romanian seasonal workers who had migrated at an older age, had a partner in the home country, and had no intention to stay for the long term. These migrants hardly spoke Dutch, had few contacts with native Dutch, did not regularly follow Dutch news, had a weak labour market position, and were unlikely to have a Dutch bank account.

- Bi-national migrants strongly attached to both countries. This category was made up mainly of highly skilled Polish migrants, who earned a relatively higher income and had no intention to stay for the long term. Though socially and economically integrated, they nonetheless maintained contacts with friends and relatives in the homeland, sent remittances, and had property there. Their transnational connections were fostered by their higher income.

- Footloose migrants with weak attachment to both countries. These tended to be relatively young, less-skilled migrants without a working permit and intending to stay less than a year. They did not speak Dutch, had little contact with the Dutch, and were unemployed or worked informally.

- Settlement migrants with weak attachment to the country of origin and strong attachment to the country of destination. This category consisted mainly of highly educated Romanians and Bulgarians who intended to stay at least five years and worked in skilled professions. They spoke fluent Dutch and engaged in Dutch social life.

These findings, Engbersen et al. $(2013,978)$ argue, demonstrate that there is no strong connection between homeland attachment and integration. However, the analysis shows that integration can go hand in hand with either strong or weak forms of transnationalism. 
A quantitative study of 1,270 immigrant respondents belonging to "old" immigrant groups in the Netherlands (Turks, Moroccans, Surinamese, and Antilleans) showed that $90 \%$ of them maintained contact with relatives in the country of origin (Schans 2009). The type of family ties, however, differed. Moroccans and Turks were more inclined to have face-to-face contact with relatives than Surinamese and Antilleans. Since Suriname and the Antillean islands can be reached only by plane from the Netherlands 'this might indicate that the costs of travelling are too high for many respondents' (ibid., 1178). Another explanation mentioned is that transnational practices result from migrants' dissatisfaction with their life in the Netherlands. In the past decade, Turks and Moroccans as Muslim groups have 'faced increasingly negative perceptions regarding their culture and religion. Under such circumstances, family ties and identification with their country of origin remain or may even become more important' (ibid., 1179). Similar patterns are found among other groups, such as Albanian youngsters in Tuscany (Vathi 2013).

Bivand Erdal (2013) qualitatively studied the relation between social integration and engagement in sociocultural transnational activities from migrants' own perspective. This author asked Pakistanis in Norway their thoughts about possible links between transnationalism and integration. Most respondents indicated seeing 'integration primarily as a structural and functional issue' and considered transnational activities a cultural issue with no direct relation to 'integration' (ibid., 994). The Pakistani respondents in this study considered sentiments of dual loyalty-feeling Pakistani and helping the homeland while at the same time working and raising children in Norway-to be perfectly compatible. However, they felt that this perspective was not shared by the Norwegian majority. For respondents, cultural issues were largely outside the realm of integration (ibid., 995).

Nagel and Staeheli (2008) studied 45 Arab activists in the UK. Though they had different backgrounds, they had a shared political and cultural commitment to the Arab world - enacted through their engagement with Arab organizations and politics. They expressed their feelings of responsibility towards their countries of origin and to Arab people as a whole (ibid., 422). Yet, despite strong emotional attachments to the Arab world, there was also 'a strong sense of realism among them that "here" - their local neighbourhoods, their city, and Britain as a whole-is where they send their children to school, where they work, and where they should have a voice in policies that affect them and their families' (ibid., 424). Respondents suggested that integration is a "two-way affair" involving different but equal groups. Their position was pragmatic: they had transnational feelings of belonging but spoke of the need to combat minority self-segregation and isolation from mainstream life.

Dahinden (2009) conducted a network analysis of 250 persons in Neuchâtel, a small city in Switzerland, to understand how transnationalism is practised through social relations. Overall $30 \%$ of the subjects' networks consisted of personal relations. The findings first show that 'being born outside Switzerland and not having Swiss nationality enhances network transnationalism' (Dahinden 2009, 1375). Second, the author found that transnationalism diminishes with length of stay. This study furthermore emphasizes that mobility-having lived in different countriesas well as high cultural capital—a good education-was associated with strong 
transnationalism. Others who engaged in what Dahinden labels as pronounced transnationalism were the 'transnational outsiders': third-country nationals with low education who find themselves in 'unprivileged and disadvantaged socioeconomic situations' (ibid., 1377-1388). They had applied for asylum but been granted only annual residence permits. Strong transnational networks may signify a favourable social position for the highly skilled, even though they may not be locally integrated. But for the less skilled - the outsiders - it may reflect social exclusion and a lack of integration. Medium transnational networks were maintained by so-called guest workers. Their networks were both localized and transnational. The respondents with the weakest transnationalism were those born in Neuchâtel who had not been internationally mobile. Their networks were therefore locally focused (ibid., 1376).

Does transnationalism wane over time? Put differently, does the second generation feel less connected to the parental country of origin than the first generation? In her ethnographic work among Italians in Switzerland, Wessendorf (2007) concludes that transnational feelings of belonging among the second generation sometimes lead to a "return" to their "roots". Such return migration paradoxically was characterized as the 'loss of roots': While still in Switzerland, an important part of their identity was based on the longing for, and belonging to, their parents' homeland. Once in Italy, they lose this feeling and feel trapped in a place which they once hoped would be their homes, but in which they feel like strangers (ibid., 1097).

The Kurdish experience in Sweden is different. As "Kurdistan" is not an official country, the diasporic community and movement established over various locations have become the 'diasporic home where [Kurds] can find a sense of continuity and belonging' (Alinea and Eliassi 2014, 79). For the older generation identity is not constructed in opposition to the Swedish identity, but in opposition to identities in their cultures of origin (Turkish, Arabic, and Persian). For the younger generation, the Swedish context is more influential. For them, feelings of exclusion from Swedish society strengthen essentialist notions of Kurdish identity (ibid.). Thus, for the older generation feelings of exclusion in the country of origin determine feelings of belonging, while for the younger generation the context of the host country is more significant. Despite differences in identification, the Italian and Kurdish cases underline that feeling excluded in the (parental) country of origin is as influential for transnationalism and integration as feeling excluded in the host country.

\section{Challenges for Future Policy-Oriented Research}

The breadth of approaches and foci on actors and types of transnationalism provide insight into some broad patterns. The joint reading of the current literature on transnationalism in Europe points to two main observations. First, transnationalism is costly. Economic transnationalism requires financial capital, for instance, for remittances or investments. Sociocultural transnationalism requires social capital in the form of available contacts, but also money to buy phone cards or airplane tickets. Political transnationalism requires political capital in the form of skills, knowledge, 
and contacts to work politics in the homeland. Put differently, immigrants who are low on economic, sociocultural, or political resources are less likely to engage in transnationalism. How this relates to integration depends on the type and form of transnationalism. For instance, it is relatively inexpensive for immigrants to respond to country of residence transnational activities since this is paid by homeland based actors (such as political parties or religious organizations). But only those who earn enough to send money to relatives or invest in property - and thus who are economically integrated in the host country - can afford to engage in homeland-directed economic transnational activities. Second, many studies show that what happens "there" has consequences for what happens "here". Feelings of exclusion in the homeland may foster integration in the host county, while factual exclusion from politics may trigger more radical forms of transnationalism to change the situation in the homeland. Either way, homeland developments are decisive for the form and direction of transnationalism. It is therefore surprising that it is so often left out of typologies and reviews on transnationalism (but see Pitkänen et al. 2012).

The current state of the art suggests two avenues for future policy-relevant research. First, comparable data on transnational activities should be collected in European Union member states. National governments have thus far tended to take transnationalism into account reactively, when they believe transnationalism is undermining integration. However, many European countries do monitor citizens' social, cultural, and economic positions and, in one way or another, examine their ethnic minorities' integration. While issues related to the country of origin are prominent in public and political debates, they are poorly reflected in official statistics. Hence, our knowledge about the transnational orientations of individual migrants remains limited.

The second issue that merits scholarly attention is the role of gender and sexuality in transnationalism. Despite scholarly agreement that gender matters in all social, economic, and political spheres, little research has addressed gender outside of typically "female" spaces, like the household (Mahler 1998; but see Sinatti 2013). Existing scholarship suggests that involvement in social networks and transnationalism takes very different forms for migrant men and women (De Tona and Lentin 2011; Hagan 1998; Itzigsohn and Giorguli-Saucedo 2005, 896). The general perception is that migrant men play a role in public, formal, and institutionalized domestic networks of migrant organizations and in the transnational ties these maintain with homeland-based actors. In contrast, women seem to play an important role in informal networks consisting of friends and family. In other words, migrant women do not succeed in getting out of the transnational "private sphere" (Mügge 2013b). Thus, gendering transnationalism raises new questions about who is involved in what role and in what type of transnationalism. Finally, a sexuality prism opens routes to study the transnational experiences of lesbian, gay, bisexual, transsexual, and queer (LGBTQ) groups. This would be particularly welcome, given the salience of inclusion and exclusion of these groups across the globe and the prominence of LGBTQ issues on the European policy agenda. Promising topics for study are, for instance, same-sex marriage migration, adoption of children by same-sex couples, and transnational political activism by migrants who escaped oppression on the basis of their sexual preference. 
Open Access This chapter is distributed under the terms of the Creative Commons AttributionNoncommercial 2.5 License (http://creativecommons.org/licenses/by-nc/2.5/) which permits any noncommercial use, distribution, and reproduction in any medium, provided the original author(s) and source are credited.

The images or other third party material in this chapter are included in the work's Creative Commons license, unless indicated otherwise in the credit line; if such material is not included in the work's Creative Commons license and the respective action is not permitted by statutory regulation, users will need to obtain permission from the license holder to duplicate, adapt or reproduce the material.

\section{References}

Al-Ali, N., Black, R., \& Koser, K. (2001). Refugees and transnationalism: The experience of Bosnians and Eritreans in Europe. Journal of Ethnic and Migration Studies, 27(4), 615-634.

Alinea, M., \& Eliassi, B. (2014). Temporal generational impact on identity, home(land) and politics of belonging among the Kurdish diaspora. Nordic Journal of Migration Research, 4(2), 73-81.

Alinea, M., Wahlbeck, Ö., Eliassi, B., \& Khayati, K. (2014). The Kurdish diaspora: Transnational ties, home and politics of belonging. Nordic Journal of Migration Research, 4(2), 53-56.

Arthur, P. (1991). Diasporan intervention in international affairs: Irish America as a case study. Diaspora: A Journal of Transnational Relations, 1(2), 143-162.

Ban, C. (2012). Economic transnationalism and its ambiguities: The case of Romanian migration to Italy. International Migration, 50(6), 129-149.

Basch, L., Glick Schiller, N., \& Szanton Blanc, C. (1994). Nations unbound: Transnational projects, postcolonial predicaments and deterritorialized nation-states. Langhorne: Gordon and Breach Science Publishers.

Baser, B. (2011). Kurdish diaspora political activism in Europe with a particular focus on Great Britain: Diaspora dialogues for development and peace project. Berlin: Berghof Peace Support.

Baser, B. (2014). The awakening of a latent diaspora: The political mobilization of first and second generation Turkish migrants in Sweden. Ethnopolitics, 13(4), 355-376.

Berkowitz, L., \& Mügge, L. (2014). The potential and limits of EU opportunity structures for diaspora lobbying: The Kurdish question. Journal of Intercultural Studies, 35(2), 74-90.

Bivand Erdal, M. (2013). Migrant transnationalism and multi-layered integration: NorwegianPakistani migrants' own reflections. Journal of Ethnic and Migration Studies, 39(6), 983-999.

Bivand Erdal, M., \& Oeppen, C. (2013). Migrant balancing acts: Understanding the interactions between integration and transnationalism. Journal of Ethnic and Migration Studies, 39(6), 867-884.

Carling, J., \& Hoelscher, K. (2013). The capacity and desire to remit: Comparing local and transnational influences. Journal of Ethnic and Migration Studies, 39(3), 939-958.

Collyer, M. A. (2014). Geography of extra-territorial citizenship: Explanations of external voting. Migration Studies, 2(1), 55-72.

Dahinden, J. (2009). Are we all transnationals now? Network transnationalism and transnational subjectivity: The differing impacts of globalization on the inhabitants of a small Swiss city. Ethnic and Racial Studies, 32(8), 1365-1386.

De Tona, C., \& Lentin, R. (2011). Networking sisterhood, from the informal to the global: AkiDwa, the African and migrant women's network, Ireland. Global Networks, 11(2), 242-261.

Dunn, K. M. (2005). A paradigm of transnationalism for migration studies. New Zealand Population Review, 31(2), 15-31. 
Dunn, K. M. (2010). Embodied transnationalism: Bodies in transnational spaces. Guest editorial. Population, Space and Place, 16(1), 1-9.

Eliassi, B. (2013). Contesting Kurdish identities in Sweden: Quest of belonging among Middle Eastern youth. Basingstoke: Pallgrave Macmillan.

Engbersen, G., Leerkes, A., Grabowska-Lusinska, I., Snel, E., \& Burgers, J. (2013). On the differential attachments of migrants from central and Eastern Europe: A typology of labour. Migration Journal of Ethnic and Migration Studies, 39(6), 959-981.

Faist, T., \& Kivisto, P. (Eds.). (2007). Dual citizenship in global perspective. New York: Palgrave Macmillan.

Foner, N. (2000). Anthropology and the study of migration. In N. Foner, R. G. Rumbaut, \& S. J. Gold (Eds.), Immigration research for a new century: Multidisciplinary perspectives (pp. 49-54). New York: Russell Sage.

Freeman, G. P., \& Ögelman, N. (1998). Homeland citizenship policies and the status of third country nationals in the European Union. Journal of Ethnic and Migration Studies, 24(4), 769-788.

Garett, S. A. (1978). Eastern European ethnic groups and American foreign policy. Political Science Quarterly, 93(2), 301-323.

Guarnizo, L. E., Portes, A., \& Haller, W. (2003). Assimilation and transnationalism: Determinants of transnational political action among contemporary migrants. American Journal of Sociology, 108(6), 1211-1248.

Gunter, M. (2008). The Kurds ascending: The evolving solution to the Kurdish problem in Iraq and Turkey. New York: Palgrave Macmillan.

Hagan, J. M. (1998). Social networks, gender and immigrant incorporation: Resources and constraints. American Sociological Review, 63(1), 55-67.

Hammond, L. (2013). Somali transnational activism and integration in the UK: Mutually supporting strategies. Journal of Ethnic and Migration Studies, 39(6), 1001-1017.

Huntington, S. P. (1997). The erosion of American national interests. Foreign Affairs, 76(5), 28-49.

Itzigsohn, J., \& Giorguli-Saucedo, S. (2005). Incorporation, transnationalism, and gender: Immigrant incorporation and transnational participation as gendered process. International Migration Review, 39(4), 895-920.

Jusdanis, G. (1991). Greek Americans and the diaspora. Diaspora: A Journal of Transnational Relations, 1(2), 209-223.

Kasinitz, P., Waters, M. C., Mollenkopf, J. H., \& Anil, M. (2002). Transnationalism and the children of immigrants in contemporary New York. In P. Levitt \& M. C. Waters (Eds.), The changing face of home: The transnational lives of the second generation (pp. 96-122). New York: Russell Sage.

Katoryano, R. (2005). Citizenship, nationhood, and non-territoriality: Transnational participation in Europe. PS Political Science and Politics, 38(4), 693-696.

Khayati, K., \& Dahlstedt, M. (2014). Diaspora formation among Kurds in Sweden: Transborder citizenship and politics of belonging. Nordic Journal of Migration Research, 4(2), 57-64.

Kivisto, P. (2001). Theorizing transnational immigration: A critical review of current efforts. Ethnic and Racial Studies, 24(4), 549-577.

Koopmans, R., Statham, P., Giugni, M., \& Passy, F. (2005). Contested citizenship: Immigration and cultural diversity in Europe. Minneapolis: University of Minnesota Press.

Kruijt, D., \& Maks, M. (2003). Een belaste relatie: 25 jaar ontwikkelingssamenwerking NederlandSuriname, 1975-2000. The Hague: Ministry of Foreign Affairs and Paramaribo: Ministry of Planning and Development.

Lacroix, T. (2013). Collective remittances and integration: North African and North Indian comparative perspectives. Journal of Ethnic and Migration Studies, 39(6), 1019-1035.

Levitt, P., \& De la Dehesa, R. (2003). Transnational migration and the redefinition of the state: Variations and explanations. Ethnic and Racial Studies, 26(4), 587-611.

Levitt, P., \& Schiller, N. G. (2004). Conceptualizing simultaneity: A transnational social field perspective on society. International Migration Review, 38(3), 1002-1039.

Ley, D. (2013). Does transnationalism trump immigration integration? Evidence from Canada's links with East Asia. Journal of Ethnic and Migration Studies, 39(6), 921-938. 
Mahler, S. (1998). Theoretical and empirical contributions: Toward a research agenda for transnationalism. In M. P. Smith \& L. E. Guarnizo (Eds.), Transnationalism from below (pp. 64-102). New Brunswick: Transaction Publishers.

Marger, M. (2006). Transnationalism or integration? Patterns of socio-political adaptation among Canadian business immigrants. Ethnic and Racial Studies, 29(5), 882-900.

Martiniello, M., \& Lafleur, J. M. (2008). Towards a transatlantic dialogue in the study of immigrant political transnationalism. Ethnic and Racial Studies, 31(4), 645-663.

Mathias, C. M. J. (1981). Ethnic groups and foreign policy. Foreign Affairs, 59(5), 975-998.

Mazzucato, V. (2008). The double engagement: Transnationalism and integration. Ghanaian migrants' lives between Ghana and the Netherlands. Journal of Ethnic and Migration Studies, 34(2), 199-216.

Morawska, E. (2003). Immigrant transnationalism and assimilation: A variety of combinations and the analytic strategy it suggests. In C. Joppke \& E. Morawska (Eds.), Toward assimilation and citizenship: Immigrants in liberal nation-states (pp. 133-176). New York: Palgrave Macmillan.

Mügge, L. (2010). Beyond Dutch borders: Transnational politics among colonial migrants, guest workers and the second generation. IMISCOE Research. Amsterdam: Amsterdam University Press.

Mügge, L. (2011). Diversity in transnationalism: Surinamese organizational networks. International Migration, 49(3), 52-75.

Mügge, L. (2012a). Dual nationality and transnational politics. Journal of Ethnic and Migration Studies, 38(1), 1-19.

Mügge, L. (2012b). Ethnography's contribution to newspaper analysis: Claims-making revisited (Open Forum CES paper series 12). Cambridge, MA: The Minda de Gunzberg Center for European Studies at Harvard University.

Mügge, L. (2013a). Ideologies of nationhood in sending-state transnationalism: Comparing Surinam and Turkey. Ethnicities, 13(3), 338-358.

Mügge, L. (2013b). Women in transnational migrant activism: Supporting social justice claims of homeland political organizations. Studies in Social Justice, 7(1), 65-81.

Mügge, L., \& De Jong, S. (2013). Intersectionalizing European politics: Bridging gender and ethnicity. Politics, Groups and Identities, 1(3), 380-389.

Nagel, C. R. (2009). Rethinking geographies of assimilation. The Professional Geographer, 61(3), 400-407.

Nagel, C. R., \& Staeheli, L. A. (2008). Integration and the negotiation of "here" and "there": The case of British Arab activists. Social and Cultural Geography, 9(4), 415-430.

Nell, L. M. (2007). Locally specific transnational political ties: Turkish and Turkish Kurdish immigrants in the Netherlands. In A. Guillou, S. de Tapia, \& M. Wadbled (Eds.), Migrations Turques dans un monde globalisé: Le poids du local (pp. 199-216). Rennes: Rennes University Press.

Østergaard-Nielsen, E. (2001). Transnational political practices and the receiving state: Turks and Kurds in Germany and the Netherlands. Global Networks, 1(3), 261-282.

Østergaard-Nielsen, E. (2011). Codevelopment and citizenship: The nexus between policies on local migrant incorporation and migrant transnational spaces in Spain. Ethnic and Racial Studies, 34(1), 20-39.

Penninx, R. (1988). Minderheidsvorming en emancipatie: Balans van kennisverwerving ten aanzien van immigranten en woonwagenbewoners. Samsom: Alphen aan de Rijn/Brussels.

Pitkänen, P., Içduygu, A., \& Sert, D. (Eds.). (2012). Migration and transformation: Multi-level analysis of migrant transnationalism. Dordrecht: Springer.

Portes, A. (1999). Conclusion: Towards a new world. The origins and effects of transnational activities. Ethnic and Racial Studies, 22(2), 463-477.

Portes, A. (2001). Introduction: The debates and significance of immigrant transnationalism. Global Networks, 1(3), 181-194.

Portes, A., Guarnizo, L. E., \& Landholt, P. (1999). The study of transnationalism: Pitfalls and promise of an emergent research field. Ethnic and Racial Studies, 22(2), 217-231. 
Portes, A., Escobar, C., \& Radford, A. (2007). Immigrant transnational organizations and development: A comparative study. International Migration Review, 41(1), 242-281.

Schans, D. (2009). Transnational family ties of immigrants in the Netherlands. Ethnic and Racial Studies, 32(7), 1164-1182.

Shain, Y. (1999). Marketing the American greed: Diasporas in the US and their homelands. Cambridge: Cambridge University Press.

Sinatti, G. (2013). Masculinities and intersectionality in migration: Transnational Wolof migrants negotiating manhood and gendered family roles. In T. D. Truong \& S. Bergh (Eds.), Migration, gender and social justice: Perspectives on human security (pp. 215-226). Berlin/Heidelberg/ New York: Springer.

Snel, E., Engbersen, G., \& Leerkes, A. (2006). Transnational involvement and social integration. Global Networks, 6(3), 285-308.

Unger, B., \& Siegel, M. (2006). The Netherlands-Suriname remittance corridor prospects for remittances when migration ties loosen (Study for the World Bank and Netherlands Ministry of Finance). Utrecht: Utrecht University.

Van Amersfoort, H. (2001). Moderne diaspora's, transnationalisme en sociale cohesie. Amsterdam: Institute for Social Science Research, University of Amsterdam.

Van den Bos, M., \& Nell, L. (2006). Territorial bounds to virtual space: Transnational online and offline networks of Iranian and Turkish-Kurdish immigrants in the Netherlands. Global Networks, 6(2), 201-220.

Vathi, Z. (2013). Transnational orientation, cosmopolitanism and integration among Albanianorigin teenagers in Tuscany. Journal of Ethnic and Racial Studies, 39(6), 903-919.

Vertovec, S. (2003). Migration and other modes of transnationalism: Towards conceptual crossfertilization. International Migration Review, 37(3), 641-665.

Vertovec, S. (2009). Transnationalism. New York: Routledge.

Wahlbeck, Ö. (1999). Kurdish diasporas: A comparative study of Kurdish refugee communities. London: Macmillan.

Weil, M. (1974). Can the blacks do for Africa what the Jews did for Israel? Foreign Policy, 15 , 109-130.

Wessendorf, S. (2007). "Roots migrants": Transnationalism and "return" among second-generation Italians in Switzerland. Journal of Ethnic and Migration Studies, 33(7), 1083-1102. 